Historic, Archive Document

Do not assume content reflects current scientific knowledge, policies, or practices. 



\title{
SPRING OF 1905.
}

\section{TRADE LIST}

OF THE

\section{MOUNT HOPE NURSERIES \\ ROCHESTER, N. Y.}

\section{ELLWANGER \& BARRY, PROPRIETORS.}

\author{
Established, 1840.
}

We take pleasure in presenting herewith our Wholesale Catalogue or Trade List for the Spring of 1905.

The stock herein offered is of the best quality in all respects and well worthy the attention of Dealers, Nurserymen, and Planters.

We keep all our departments fully up to the times, adding every new variety of merit as soon as we are satisfied of its value.

Our collections are carefully examined every year, and such things as seem to have little or no value are discarded. In this way we offer to our customers assortments which we can recommend with the greatest confidence.

The extent and completeness of the collections of both Fruit and Ornamental Departments of these Nurseries, their reputation for accuracy, which is scrupulously maintained; the long experience of the Proprietors and their assistants, in digging, packing, shipping, and in every detail of Nursery work, are well worthy the consideration of purchasers. No pains will be spared to insure satisfaction to those who favor us with their orders.

\section{THE SPRING PACKING SEASON.}

The Spring packing and shipping season usually opens here about the first of April and continues into the month of May. The planting season is not regulated by any particular month or day, nor by the state of vegetation where the planting is to be done, but by the condition of the trees to be planted. Hence, trees can be sent with safety from Rochester to localities several degrees south, even if they do not arrive until after the ordinary transplanting season in that locality has passed.

\section{DIRECTIONS FOR SHIPPING.}

Parties ordering are requested to state explicitly the mode of conveyance by which they desire their trees forwarded. When no route is designated, we exercise our judgment; but in no case do we assume any responsibility after the packages are shipped, unless for our own mistakes. When losses occur by detention, claims should at once be made on the forwarder. 


\section{CONDITIONS OF SALE.}

FIrst-The articles in the following list will be furnished at the annexed prices.only when the quantity specified shall be taken. Five hundred will be furnished at the thousand rate, fifty at the hundred rate, and five at the rate per ten. In no case will we supply long lists of selected varieties, two or three of each, of either Fruit or Ornamental Trees or Plants, to Nurserymen or others, at wholesale rates, but at such a discount from retail prices as circumstances will justify. Ordinarily a discount of from 20 to $33 \frac{1}{3}$ per cent. from retail single prices will be allowed on such lists.

SECOND-In furnishing assortments of Fruit Trees, as well as Ornamental Trees, Shrubs and Plants, at the prices in this Catalogue, we reserve the right of selecting varieties, but these will be of leading popular sorts, and in all cases we will give the purchaser his choice as far as practicable.

THIRD-In growing and furnishing all nursery stock we use the greatest care to have it true to name, and will replace any that may prove untrue. But no sale by us carries a warranty of quality, express or implied, and for any error we shall not be liable for more than the purchase price. Every purchase from us is made on these terms.

FOURTH-The terms of payment, CASH, or satisfactory security before delivery or shipment of trees.

The prices annexed do not include boxes or bales, which we charge for, at cost, as follows:

Boxes (including packing) 12 feet long by 30 -inch ends ............ $\$ 50$

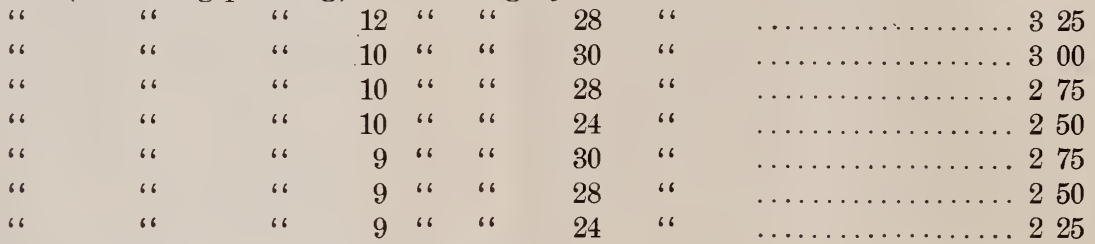

Bales, according to size, 15 cents to $\$ 2.50$.

No charge is made for conveyance from the nursery to the Railroad Station.

\section{CATALOGUES.}

Our General Catalogue of Trees, Shrubs, Roses, etc., carefully revised, beautifully illustrated with half-tone engravings, contains accurate and trustworthy descriptions of the most valuable varieties in cultivation, and is replete with practical hints, indispensable to planters. Free on request.

Wholesale Catalogue or Trade List, issued semi-annually, free.

[No. 74]

STATE OF NEW YORK.

DEPARTMENT OF Agriculture.

\section{CERTIFICATE OF INSPECTION OF NURSERY STOCK.}

This is to certify that the stock in the nursery of ELLWANGER \& BARRY, of Rochester, County of Monroe, State of New York, was duly examined in compliance with the provisions of section 83 of the Agricultural Law, and it was found to be apparently free from any contagious or infectious plant disease or diseases, or the San Jose scale or other dangerously injurious insect pest or pests. This certificate expires September 1, 1905.

Dated, Albany, N. Y., Sept. 1, 1904. 


\section{Fruit Trees, Small Fruits, Etc.}

Note.-In filling orders at the prices annexed, we reserve the right of selecting the varieties, but will consult the wishes of our customers as far as we can. Orders for select varieties will be charged at special rates. Such articles as are not enumerated in this list can be supplied in retail quantities only.

APPLES, STANDARD-First class, 5 to 7 ft. $\frac{3}{4}$ in. and up $66 \quad$ Medium, 4 to $5 \mathrm{ft}$. $\frac{5}{8}$ to $\frac{3}{4}$ in... CRAB APPLES-Standard, first class, 5 to 7 ft. $\frac{3}{4}$ in.

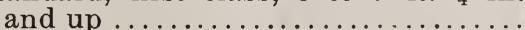
Medium, 4 to $5 \mathrm{ft}$. $\frac{5}{8}$ to $\frac{3}{4}$ in

PEARS, STANDARD-First class, 5 to $6 \mathrm{ft}$. $\frac{3}{4}$ in. and up "6 6 Medium, 4 to $5 \mathrm{ft} . \frac{5}{8}$ to $\frac{3}{4}$ in...... " DWARE-First class, 3 to $4 \mathrm{ft} \ldots \ldots \ldots \ldots \ldots$

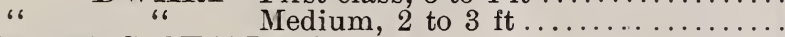
CHERRIES, STANDARD-First class, sweet........ PLUMS, STANDARD-First class, 5 to $6 \mathrm{ft} . \frac{3}{4}$ in. and up "6 "6 Medium, 3 to $5 \mathrm{ft} . \ldots \ldots \ldots \ldots \ldots$ ABUNDANCE, BuRBANK, 1 year,

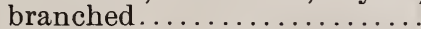

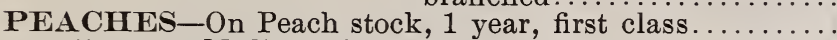

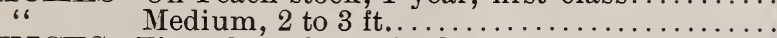
QUINCES-First class, 3 to $4 \mathrm{ft}$. ORANGE . . . . . . . .

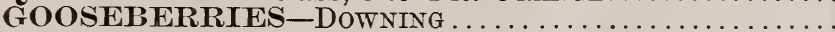

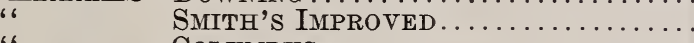

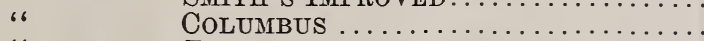
" RED JaCkET (Josselyn) $\ldots \ldots \ldots \ldots \ldots$

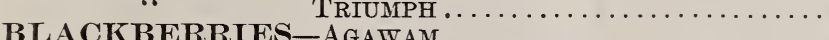

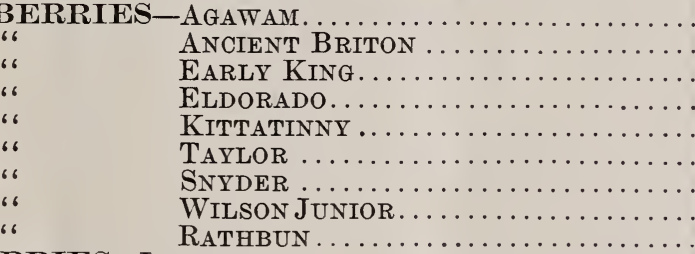
DEWBERRIES-LUCRETIA . . . . . . . . . . . . . STRAWBERRY-RASPBERRY

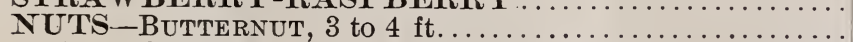

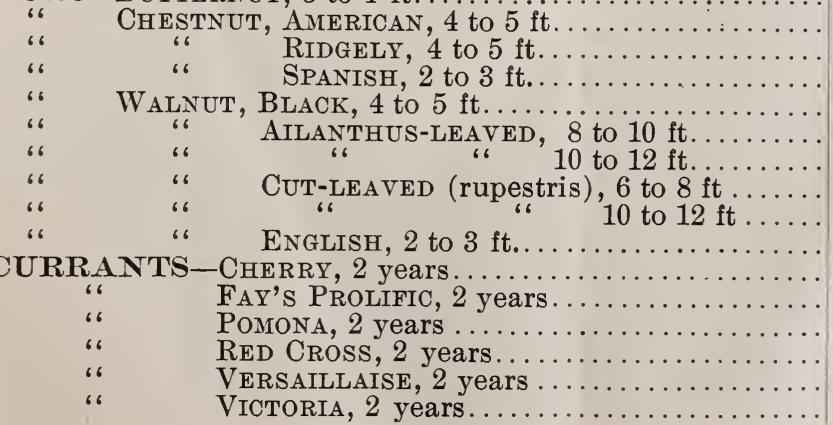

Per 10 Per 100 Per 1000 $\$ 1500 \$ 9000$ $\begin{array}{llll}12 & 00 & 60 & 00\end{array}$ 2501500 1500 1200 $2000 \quad 15000$ $\begin{array}{llll}12 & 00 & 80 & 00\end{array}$ $\begin{array}{llll}10 & 00 & 70 & 00\end{array}$ $\begin{array}{llll}8 & 00 & 40 & 00\end{array}$ 2500 2000 $2500 \quad 200 \quad 00$ $2000 \quad 15000$

1500 $\begin{array}{llll}10 & 00 & 60 & 00\end{array}$ $\begin{array}{llll}8 & 00 & 40 & 00\end{array}$ 2500 500 500 800 500 500 800

150

150

150

150

150

150

150

150

200

150 


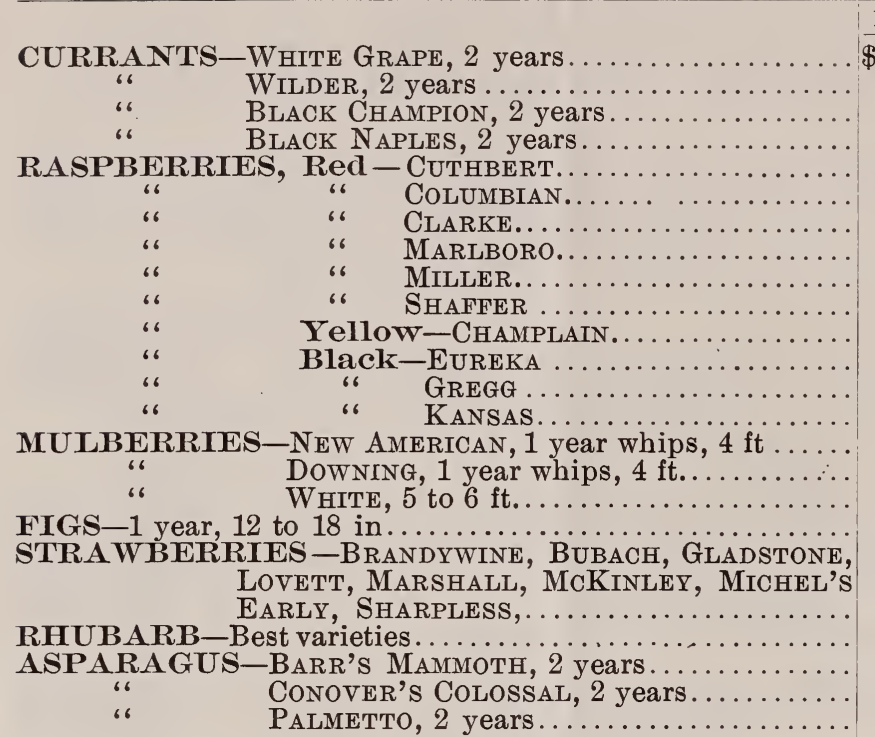

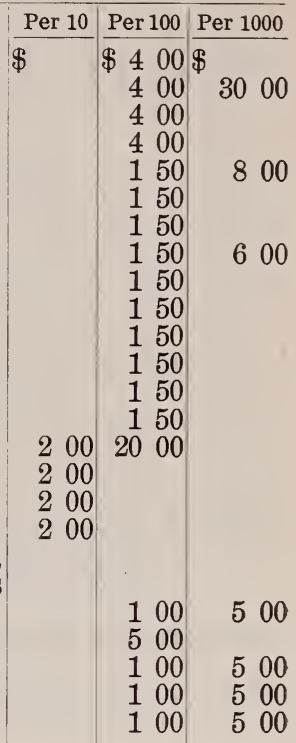

\section{HARDY GRAPES-Two Years.}

AgaWAM. (Rogers' No. 15)

\begin{tabular}{lll|l|l|l|}
1 & 00 & 5 & 00 & & \\
1 & 00 & 5 & 00 & & \\
1 & 00 & 5 & 00 & & \\
1 & 00 & 6 & 00 & 50 & 00 \\
1 & 00 & & & & \\
1 & 00 & 3 & 00 & & \\
1 & 00 & & & & \\
1 & 00 & 3 & 00 & 20 & 00
\end{tabular}

BARRY (Rogers' No. 43).

BRIGHTON

CAMPBELL'S EARLY (new).

CataWBa.

CHAMPION

100

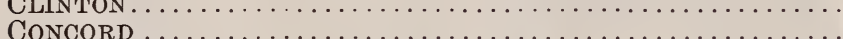

Creveling

100

DELAWARE

DIANA....

100

100

Duchess . . . . . . . . . . . . . . . . . . . . . .

100

100

EATON ...

100

EUMELAN.

GARTNER (Rogers; No. 14)

HARTFORD

Herbert (Rogers' No. 44)

100

100

100

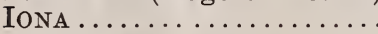

100

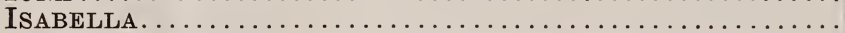

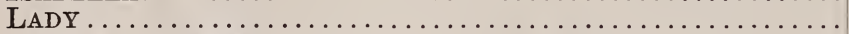

LINDLEY (Rogers' No. 9 )

LUCILE (new).

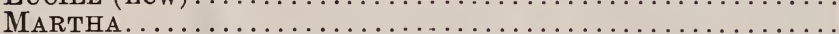

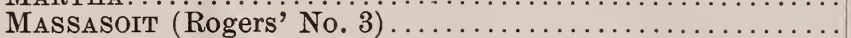

MERRIMACK

100

100

100

100

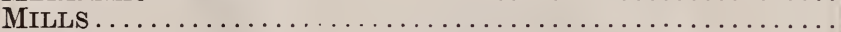

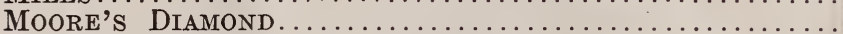

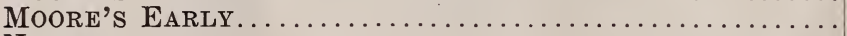

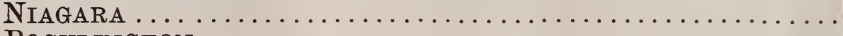

POCKLINGTON

500

100

100

100

100

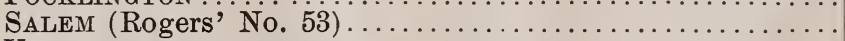

100

VERGENNES

WILDER (Rogers' No. 4)

100

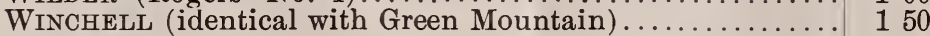

WORDEN ....................................... 100 


\section{ORNAMENTAL TREES, EVERGREENS AND SHRUBS}

\section{DECIDUOUS TREES.}

AILANTHUS-GLANDULOSA, 4 to $5 \mathrm{ft}$

ALMOND-DAVIDIANA ALBA, 3 to $4 \mathrm{ft}$.

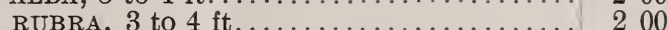

“ Large Double Flowered, 3 to $4 \mathrm{ft} \ldots \ldots \ldots \ldots \ldots .200$

Per 10 Per 100

AMELANCHIER-CANADENSIS, 2 to $3 \mathrm{ft}$.

ASH-AMERICAN WHITE, 8 to $10 \mathrm{ft}$.

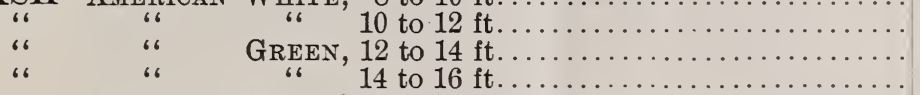

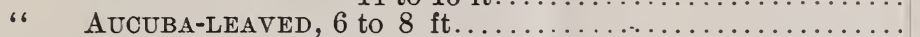

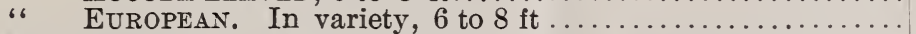

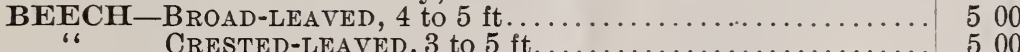

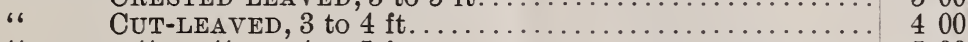

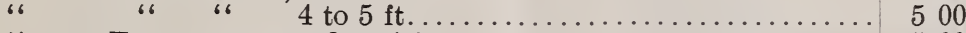

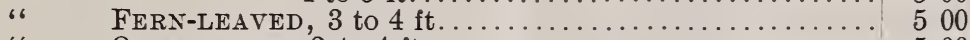

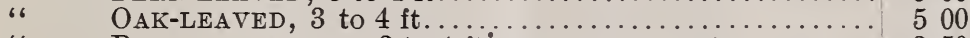

" PURPLE-LEAVED, 3 to $4 \mathrm{ft}^{\circ}$ Grafted trees, $\{\ldots \ldots \ldots \ldots 350$

"6 6 4 to $5 \mathrm{ft}\} \begin{aligned} & \text { Grafted trees, } \\ & \text { true purple. }\end{aligned} \ldots \ldots \ldots \ldots$ 4 400

“6 "6 6 to $8 \mathrm{ft}\}$ true purple. $\{\ldots \ldots \ldots \ldots .1000$

“ Purpurea Major, 3 to $4 \mathrm{ft}$ Very dark purple. $\} \ldots . . .4400$

"6 " " 4 to $5 \mathrm{ft}\}$ Very dark purple. $\}. . . .5500$

“ Rivers' Purple, 3 to $4 \mathrm{ft}$. $\}$ True Purple. $\{\ldots \ldots \ldots . . .400$

"6 " " 4 to $5 \mathrm{ft}$. $\}$ All grafted. $\{\ldots \ldots \ldots .500$

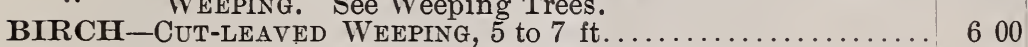

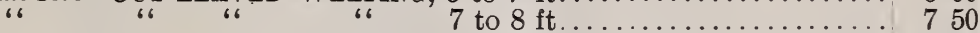

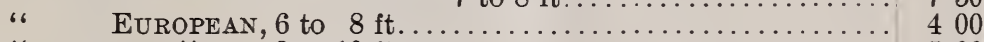

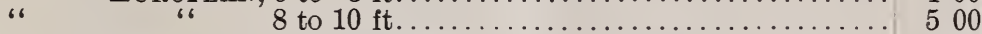

“ Fastigiata (Pyramidal Birch), 4 to $5 \mathrm{ft} . \ldots \ldots \ldots \ldots . \ldots 400$

66 66 6 6 6 to $8 \mathrm{ft} \ldots \ldots \ldots \ldots \ldots . \ldots 500$

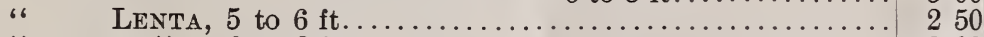

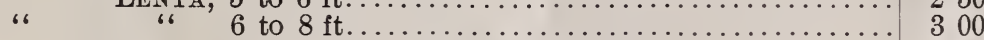

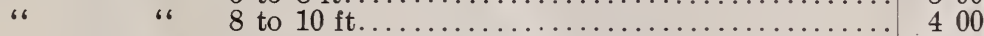

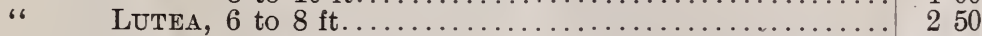

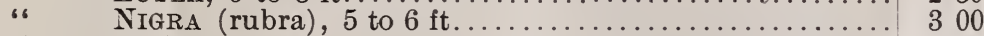

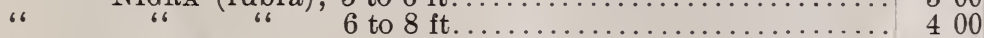

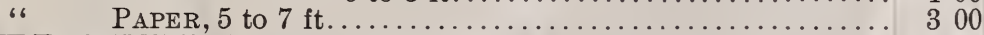

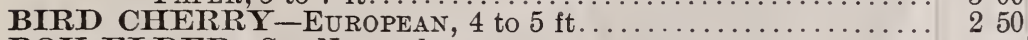

2500

2500

BOX ELDER-See Negundo.

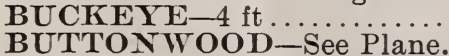

CATALPA-Bungeir, top worked, 6 to $7 \mathrm{ft} . \ldots \ldots \ldots \ldots \ldots$

JAPAN HYBRID, 8 to $10 \mathrm{ft}$.......

"6

KAMIPFERI, 6 to $8 \mathrm{ft}$

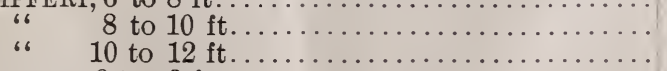

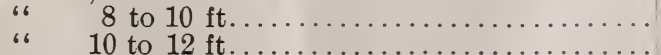

250

500

$300 \quad 2000$

$\begin{array}{ll}400 & 2500\end{array}$

500

250

300

400

Speciosa, 6 to $8 \mathrm{ft}$ 
CATALPA-SPECIOSA, 10 to $12 \mathrm{ft}$

Per $10 \quad$ Per 100

"6 12 to $14 \mathrm{ft}$.

$\$ 400 \$ 2500$

“ SYRINGEFOLIA, 6 to $8 \mathrm{ft}$

500

CHERRY-CAPRONIANA RANUNCULIFLORA, 2 to $3 \mathrm{ft}$

250

" RHEXII (DOUBLE-FLOWERED), 3 to $4 \mathrm{ft}$. Blooms young. 300

" SiEbold's Double White-FlowERED, 2 to $3 \mathrm{ft} . . . .$.

WILD BLACK (Serotina), 4 to $5 \mathrm{ft}$

300

200

CORNUS-FlORIDA. See Dogwood.

CRAB APPLE-BEChTEL'S DOUBLE-FLOWERED (New), 2 to $3 \mathrm{ft}$.

" "

66 6

FLORIBUNDA, 3 to $4 \mathrm{ft}$.

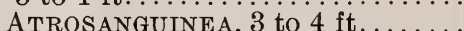

DOGWOOD-White-FLOWERED, (C. FLORIDA) 3 to $4 \mathrm{ft}$.

ELM-American, 6 to $8 \mathrm{ft}$.

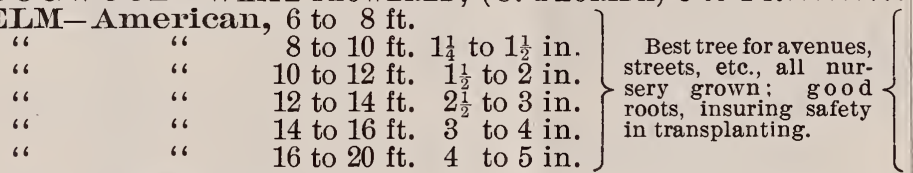

300

300

300

300

300

$300 \quad 1500$

$\begin{array}{llll}4 & 00 & 25 & 00\end{array}$

$\begin{array}{lll}500 & 3500\end{array}$

$1000 \quad 7500$

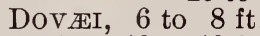

2000

5000

400

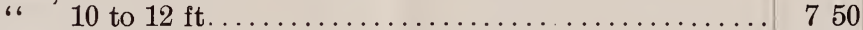

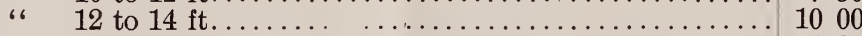

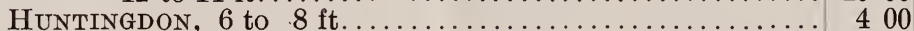

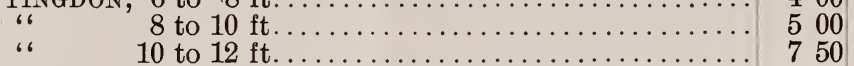

2500

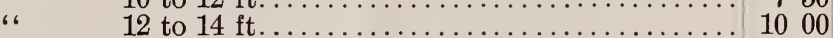

5000

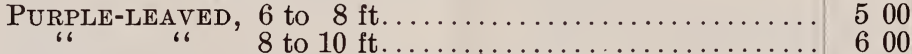

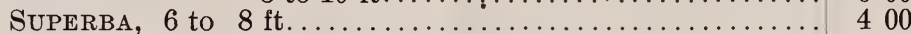

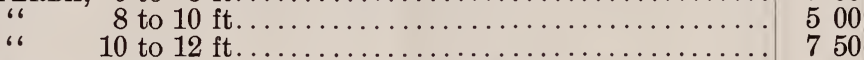

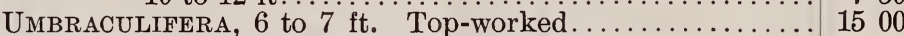

“ WeEPING, CaMPERdown. See Weeping Trees.

GINKGO-See Salisburia.

HORSE CHESTNUT-DOUble, WhITE-FLOWERED, 6 to $8 \mathrm{ft} 600$

$\begin{array}{ll}66 & 66 \\ 66 & 66 \\ 66 & 66 \\ 66 & 66 \\ 66 & 66\end{array}$

$\begin{array}{crc}\text { RED-FLOWERED, } & 4 \text { to } 5 \mathrm{ft} \ldots \ldots \ldots \ldots \ldots \\ 6 \text { "6 } & 5 \text { to } 6 \mathrm{ft} \ldots \ldots \ldots \ldots \ldots \ldots \\ \text { "6 } & 6 \text { to } 8 \mathrm{ft} \ldots \ldots \ldots \ldots \ldots\end{array}$

500

WHITE-FLOWERED, 4 to $6 \mathrm{ft} \ldots \ldots . \ldots \ldots, 300$

4 to $6 \mathrm{ft} . \ldots \ldots \ldots \ldots$
8 to $10 \mathrm{ft} . \ldots \ldots \ldots$

JUDAS TREE-AMERICAN, 3 to $4 \mathrm{ft} \ldots \ldots \ldots \ldots \ldots \ldots \ldots \ldots \ldots$

200

1500

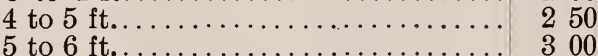

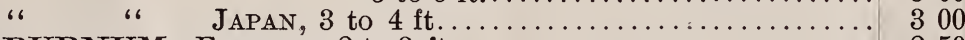

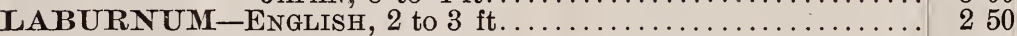

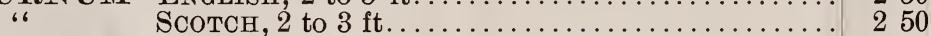

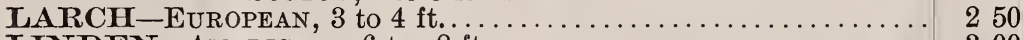

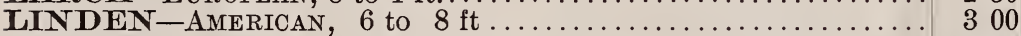

6
6
6

400

2500

500

1000

"، DASYSTYLA, 6 to $8 \mathrm{ft}$. 8 to $10 \mathrm{ft}$ Dark green, shining leaves

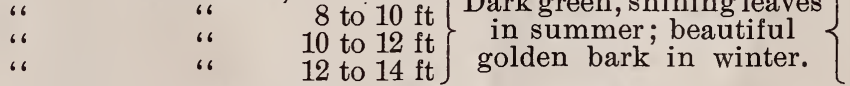

$500 \quad 4000$

$600 \quad 5000$

$\begin{array}{rr}10 & 00 \\ 5 & 00\end{array}$

، European (small-leaved), $10 \mathrm{to} 12 \mathrm{ft} \ldots \ldots \ldots \ldots \ldots \ldots \ldots, 1500$

" ،

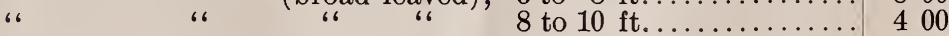

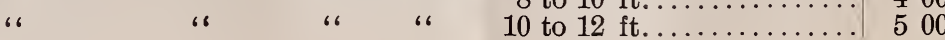

3000

4000 


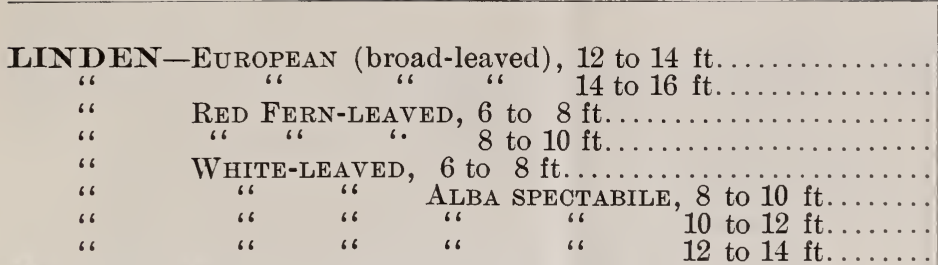

MAGNOLIA_SOUlangEANA, $3 \mathrm{ft}$. W With ball $\{\ldots \ldots \ldots \ldots \ldots 2000$ " STELlata, 2 ft..... With ball $\left\{\begin{array}{c}\ldots \ldots \ldots \ldots \ldots \ldots \\ \ldots \ldots \ldots \ldots \ldots\end{array}\right.$

MAIDEN-HAIR TREE-See Salisburia.

MAPLE-ASH-LEAVED-See Negundo.

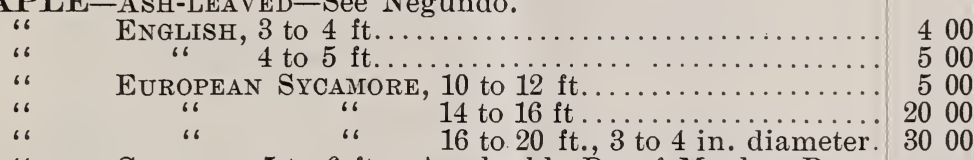

“ Ginnala, 5 to $6 \mathrm{ft}$. A valuable Dwarf Maple. Beautiful crimson foliage in autumn ................ 250

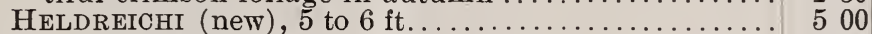

Purple-leaved Sycamore, 6 to $8 \mathrm{ft} \ldots \ldots \ldots \ldots \ldots .6 .60$

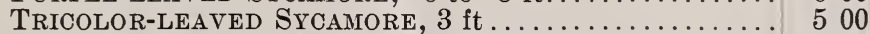

WORLE'S GOLDEN-LEAVED SYCAMORE, 5 to $6 \mathrm{ft} \ldots \ldots \ldots$..... 500

JAPAN ATROPURPUREUM, 18 to 24 in., in pots ........ 1500

" CUT-LEAVEd PURPLe, $2 \mathrm{ft}$, in pots............... 1500

NoRIVAY, 6 to $8 \mathrm{ft}$.

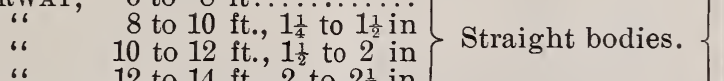

" 12 to $14 \mathrm{ft} ., 2$ to $2 \frac{1}{2}$ in

3000

500
4000

$600 \quad 5000$
15

14 to $16 \mathrm{ft}$, 3 to 4 in. ................. 3000

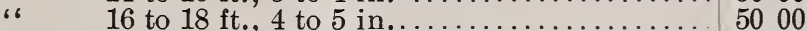

" Curled-leaved (Cucullatum), 6 to $8 \mathrm{ft}$.

" DissECTUM, 3 to $4 \mathrm{ft} \ldots \ldots \ldots \ldots \ldots \ldots \ldots \ldots$

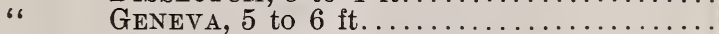

"Gold Margined-leaved, 6 to $8 \mathrm{ft} \ldots \ldots \ldots$

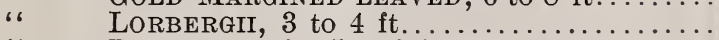

“ ReITENBACH's, 5 to $6 \mathrm{ft}\}$ Purple foliage. \{

“ ScHWEDLER's, 6 to $7 \mathrm{ft}$. Beautiful purpleleaved Norway Maple ...............

“ UNDUlatum, 5 to $\left.6 \mathrm{ft}\} \begin{array}{c}\text { Dark green } \\ 6 \text { to } 8 \mathrm{ft}\end{array}\right\}$ crinkled foliage \{

600

750

500

500

500

500

750

600

4000

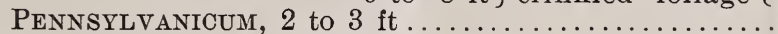

RED OR SCARLET, 5 to $6 \mathrm{ft} \ldots \ldots \ldots \ldots \ldots \ldots \ldots \ldots \ldots$

300

400

400

" “ “ GLOBE-HEADED, 5 to $6 \mathrm{ft} \ldots \ldots \ldots \ldots$

Silver-leaved oR SOFT, 6 to $8 \mathrm{ft}$ ) Handsome;

500

$200 \quad 1200$

$250 \quad 1500$

$300 \quad 2500$

$500 \quad 4000$

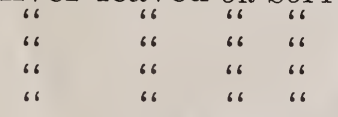

8 to $10 \mathrm{ft}$ very rapid

10 to $12 \mathrm{ft}\}$ growing tree.

14 to $16 \mathrm{ft}) 2 \frac{1}{2}$ to 3 in.diam.

750

500

750

Crispum, 5 to $6 \mathrm{ft} \quad 10$ to $12 \mathrm{ft} \ldots \ldots \ldots \ldots$

500

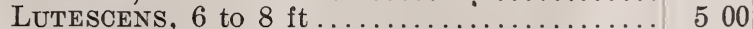

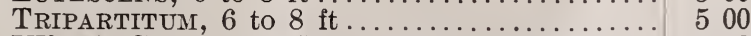

Wier's Cut-leaved, 6 to $8 \mathrm{ft}$

\begin{tabular}{|c|c|c|c|c|}
\hline el & $u_{6}$ & Ve & 1, 6 to $8 \mathrm{ft}$ & \\
\hline “6 & 66 & 66 & 8 to $10 \mathrm{ft}$ & trees. \\
\hline 66 & 66 & 66 & 12 to $14 \mathrm{ft}$ & 2 to $2 \frac{1}{x}$ in diam. \\
\hline & “6 & “6 & 14 to $16 \mathrm{ft}$ & $2 \frac{1}{2}$ to 3 in. diam. \\
\hline
\end{tabular}

SUGAR, 6 to $8 \mathrm{ft}$.

16 to $20 \mathrm{ft} \int_{3}^{2 \frac{1}{2}}$ to 4 in. diam.

$250 \quad 2000$

$300 \quad 2500$

$\begin{array}{llll}4 & 00 & 30 & 00\end{array}$

$750 \quad 6000$

1000

3000

$\begin{array}{lll}400 & 3000\end{array}$ 


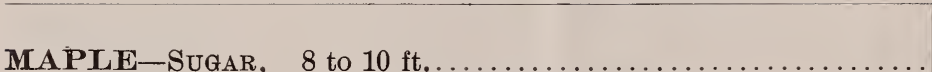
Per 10 Per 100

Ma

10 to $12 \mathrm{ft} ., 1 \frac{1}{2}$ to $2 \mathrm{in}$. in diam.

12 to $14 \mathrm{ft}$., 2 to $2 \frac{1}{2}$ in. in diam.

16 to $18 \mathrm{ft} ., 2$ to 3 in. in diam

MonUmentalis, 6 to $8 \mathrm{ft}$.

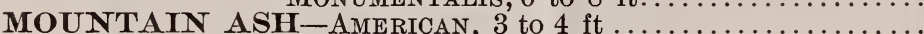

$\begin{array}{cc}66 & \text { NAIN } \\ 66 & 66 \\ 66 & 66 \\ 66 & 66 \\ 66 & 66 \\ 66 & 66 \\ 66 & 66 \\ 66 & 66 \\ 66 & 6\end{array}$

NEGUNDO-ASh-LEAVED MAPLE (BoX Elder), 6 to $8 \mathrm{ft}$...

66

6

NETTLE TRE

$\begin{array}{ll}66 & 6 \\ 66 & 66 \\ 66 & 6 \\ 66 & 6\end{array}$

DOMESTICA, 6 to $8 \mathrm{ft}$

Elder-Leaved, 6 to $8 \mathrm{ft}$.

EUROPEAN, 6 to $8 \mathrm{ft}$.

HYBRID, 4 to $5 \mathrm{ft}$

DWARF HYBRID, 4 to $5 \mathrm{ft}$

Golden HyBrid, 3 to $4 \mathrm{ft}$

MACROPHYLLA LACINIATA, 4 to $5 \mathrm{ft}$.

OAK-LEAVED, 6 to $8 \mathrm{ft}$ A desirable orna-

"6 " 8 to $10 \mathrm{ft}\}$ mental tree.

R),

8 to $10 \mathrm{ft}$

10 to $12 \mathrm{ft} . .$. .

12 to $14 \mathrm{ft} . .$.

14 to $16 \mathrm{ft} . .$.

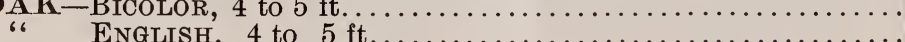

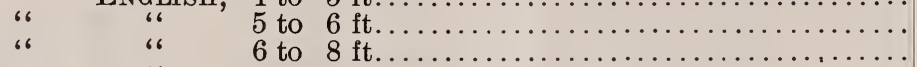

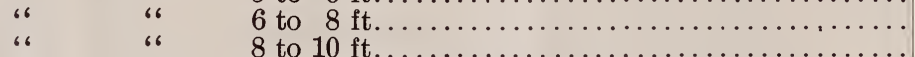

" CUT-LEAVED, 4 to $5 \mathrm{ft}$.

Mossy Cup or BuR (MACRoCARPa), 4 to $5 \mathrm{ft} \ldots \ldots \ldots \ldots$

Pin (Palustris), 5 to $6 \mathrm{ft}$ ]

" " 6 to $8 \mathrm{ft}$

"6 8 to $10 \mathrm{ft}$

6" 610 to $12 \mathrm{ft}$

"6 6 12 to $14 \mathrm{ft}$

Pyramidal Evergreen, 3 to $4 \mathrm{ft}$

"6

66

66

4 to $6 \mathrm{ft}$

8 to $10 \mathrm{ft}$
Small Fruited, 6 to $8 \mathrm{ft}$.

$\$ 500 \$ 4000$

$\begin{array}{llll}6 & 00 & 50 & 00\end{array}$

$\begin{array}{lll}15 & 00 & 7500\end{array}$

2000

750

300

300

300

250

300

300

300

300

250

400

300

300

250

300

400

500

750

300

500

300

400

500

750

750

500

500

750

1000

2000

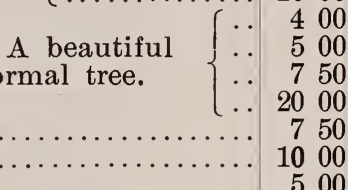

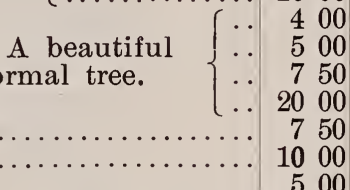

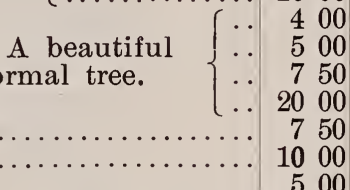

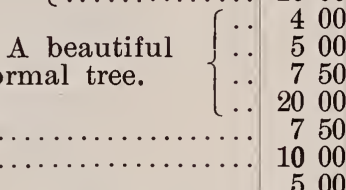

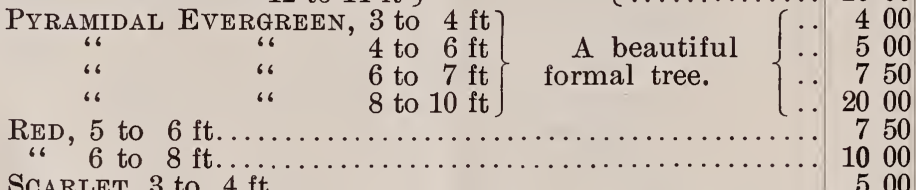

500
1000

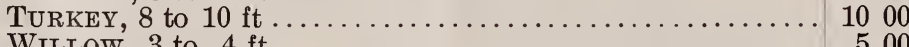

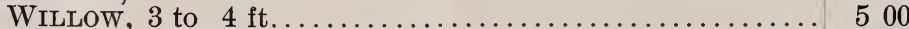

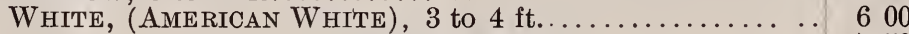

750

1000

200

200

200

200

400

$\begin{array}{llll}500 & 3500\end{array}$

. $750 \quad 5000$

$\begin{array}{llll}1500 & 100 & 00\end{array}$

8 to $10 \mathrm{ft.}, 11$

10 to $12 \mathrm{ft} ., 1 \frac{1}{2}$ to 2

14 to $16 \mathrm{ft}$, $2 \frac{1}{2}$ to 3

2000

250

$\begin{array}{llll}2 & 00 & 10 & 00\end{array}$

$\begin{array}{llll}2 & 50 & 1500\end{array}$

150

200

200

150
1000

2000

4000

5000

2500

5000

800 
Per 10 Per 100

POPLAR-Carolina, 8 to $10 \mathrm{ft}) \quad(\$ 80$ per $1000 \$ 200 \$ 1000$

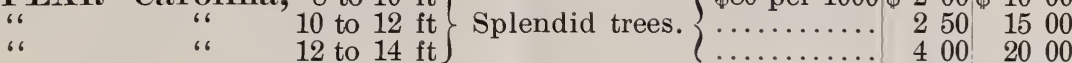

Crispa, 6 to $8 \mathrm{ft}$. 8 to $10 \mathrm{ft}$.

200

250

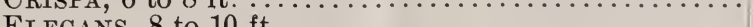

EUGENIE, 6 to $8 \mathrm{ft}$.

200

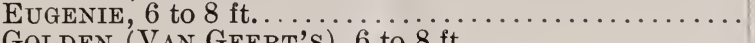

200

GOLDEN (VAN GEERT's), 6 to $8 \mathrm{ft} \ldots \ldots \ldots \ldots \ldots \ldots$

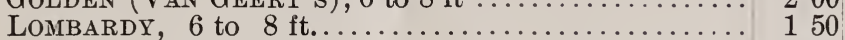

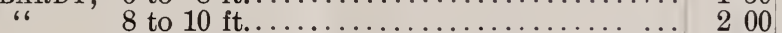

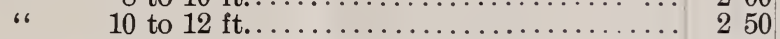

800

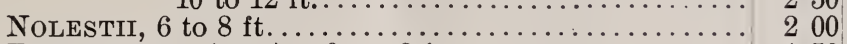

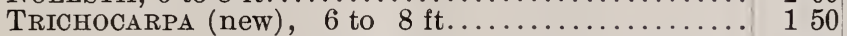

"6

SALISBURIA-(Maiden HaIr Tree, Ginkgo), 6 to $8 \mathrm{ft} . \ldots \ldots$

SWEET GUMI-(LIQUIDAMBAR), 3 to $4 \mathrm{ft} \ldots \ldots \ldots \ldots \ldots \ldots \ldots \ldots$

THORN-Double Scarlet, 4 to $5 \mathrm{ft} \ldots \ldots \ldots \ldots \ldots \ldots \ldots \ldots \ldots \ldots \ldots$

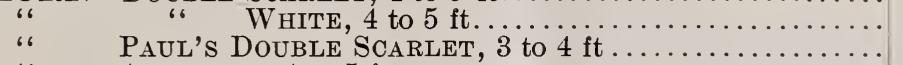

، Paul's Double Scarlet, 3 to $4 \mathrm{ft} \ldots \ldots \ldots \ldots \ldots \ldots$

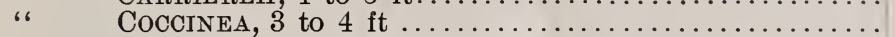

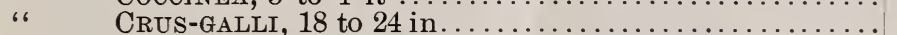

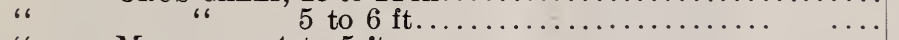

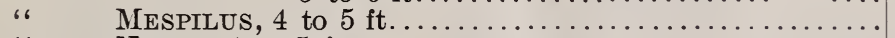

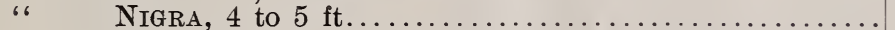

" "OXYACANTHA, 18 to 24 in ..........................

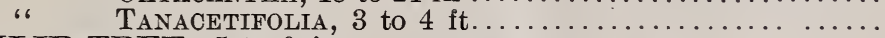

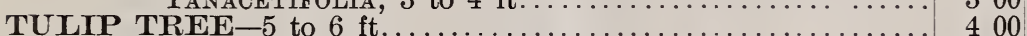

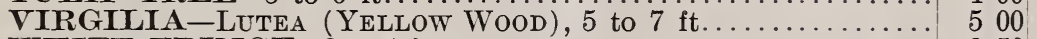

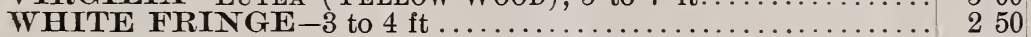

WILLOW-BRITZENSIS, 4 to $5 \mathrm{ft}$ -

200

400

300

300

300

300

300

300

$200 \quad 15.00$

$150 \quad 1000$

$\begin{array}{llll}2 & 00 & 15 & 00\end{array}$

300

300

$\begin{array}{llll}150 & 10 & 00\end{array}$

300

1000

1500

2500

2500

3000

1000

$\begin{array}{llll}2 & 00 & 1500\end{array}$

$250 \quad 2000$

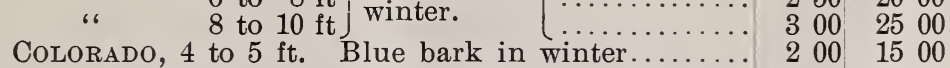

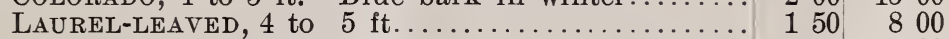

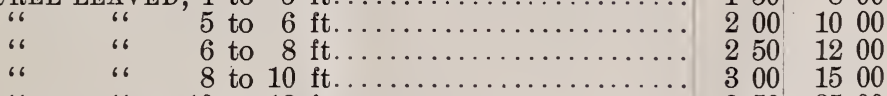

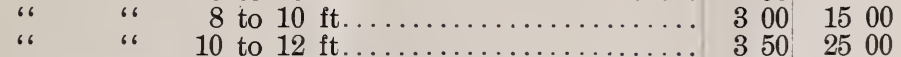

Palm-leaved, 1 year grafts, 5 to $6 \mathrm{ft} \ldots \ldots \ldots \ldots \ldots . . .250$

Regalis (Royal Willow), 5 to $6 \mathrm{ft}\} \begin{aligned} & \text { Silvery } \\ & \text { foliage. }\{\ldots\end{aligned} \ldots$

ROSEMARY-LEAVED, 3 to $4 \mathrm{ft}$. \{ Low branched, ... 200

"6 4 to $5 \mathrm{ft}$. \{ own roots.

" " 1 year heads, top-grafted, 4 to $5 \mathrm{ft}$.. 250

RUSSIAN GOLDEN, 4 to $5 \mathrm{ft}\}$ Bright golden $\{\ldots . .150$

$150 \quad 1000$

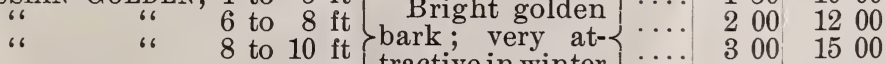

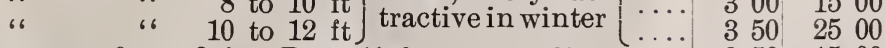

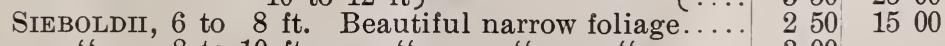

YELLOW WEEPING KILMARNOCK,

300 


\section{WEEPING DECIDUOUS TREES.}

BEECH-WeEPING, 4 to $5 \mathrm{ft}$

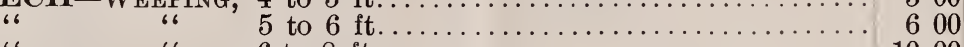

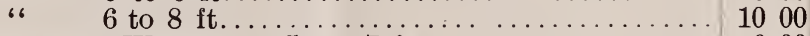

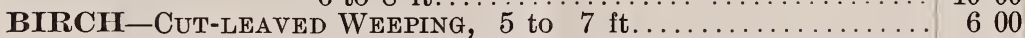

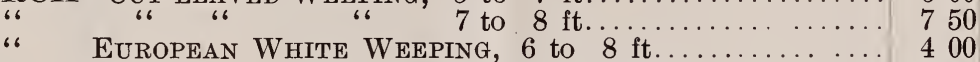

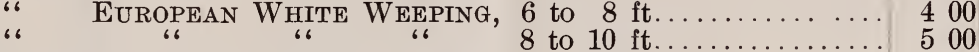

، Young's WeEPING, 1st-class .................... 1000

CHERRY-JAPONICA PENDUla, 1 year heads............... 750

"6 ROSEA PENDULA, 1 year heads........... 750

ELM-CAMPERDOWN, first-class ...................... 500

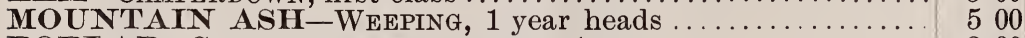

POPLAR-GRandidentata PENDUla, 1 year.............. 300

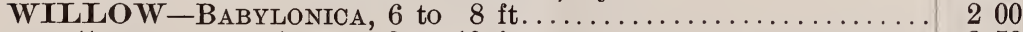

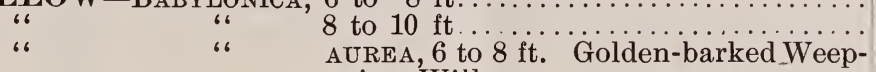

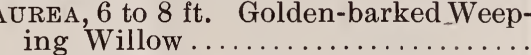

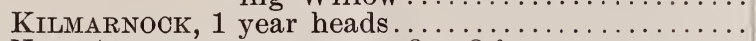

NEW AMERICAN, own roots, 2 to $3 \mathrm{ft} . \ldots \ldots \ldots \ldots \ldots$.

Rigida Pendula, own roots, 2 to $3 \mathrm{ft} . \ldots \ldots \ldots \ldots \ldots$.

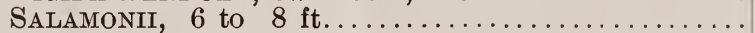

$$
\text { "6 } \quad 8 \text { to } 10 \mathrm{ft} \text {. } 10 \text { to } 12 \mathrm{ft}
$$

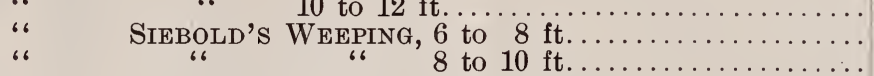

Thurlow's Weeping, 6 to $8 \mathrm{ft} \ldots \ldots \ldots \ldots \ldots \ldots \ldots \ldots$.

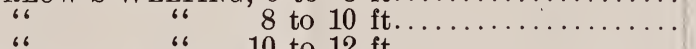

Wisconsin Weaping 10 to $12 \mathrm{ft}$ to $8 \ldots \ldots \ldots \ldots \ldots \ldots$

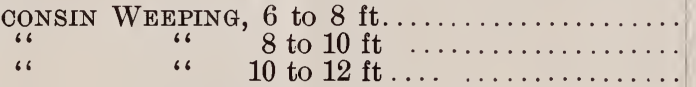

250

1500

2000

200

250

200

2000

200

200

250

300

200

250

200

250

300

200

250

300

5000

3000

2000

\section{EVERGREEN TREES.}

All transplanted, and root pruned.

ARBOR VIT $\mathbb{6}$ E-AMERICAN, 18 to 24 in $\ldots \ldots \ldots \ldots \ldots \ldots \ldots$

\begin{tabular}{|c|c|c|}
\hline 66 & " & 66 \\
\hline 66 & ، & 66 \\
\hline 66 & 6 & 66 \\
\hline 66 & 6 & 66 \\
\hline
\end{tabular}




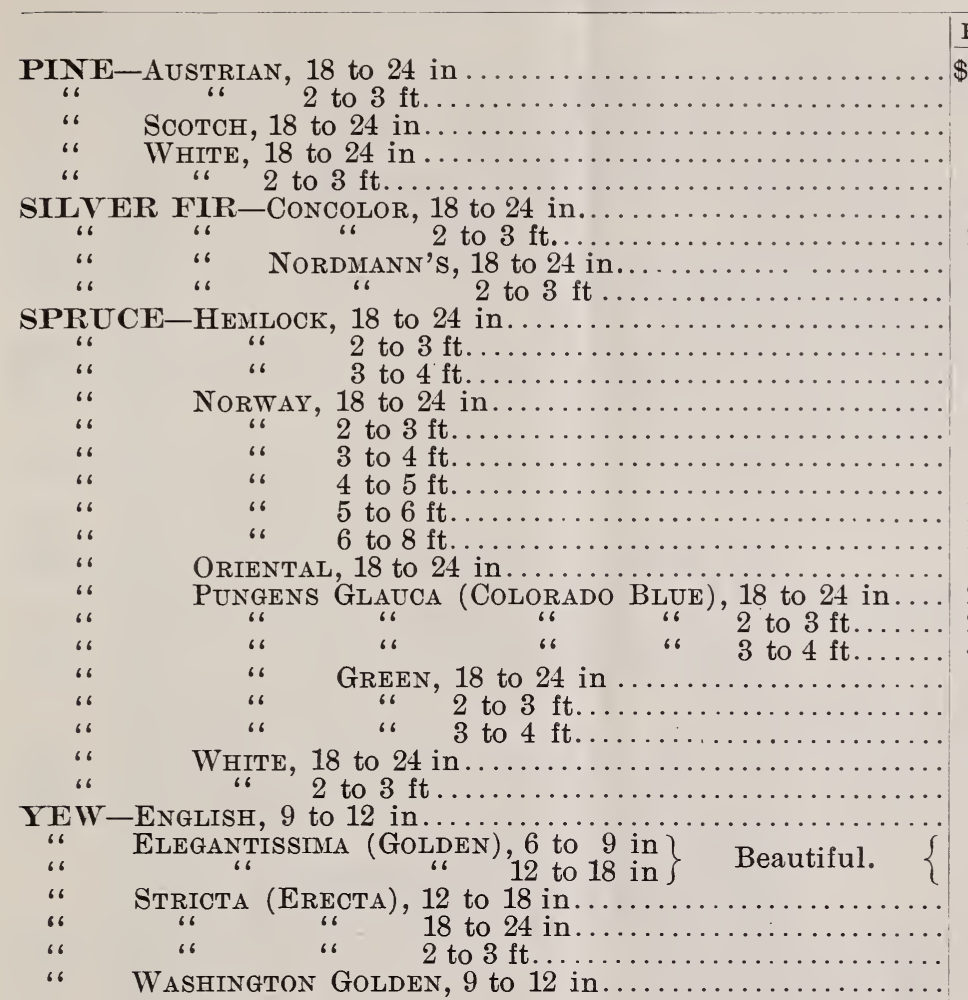

Per 10 Per 100

$\$ 200 \$$

250

200

$\begin{array}{llll}2 & 00 & 15 & 00\end{array}$

$\begin{array}{llll}250 & 2000\end{array}$

1000

2000

750

1500

300

500

750

150

200

400

500

1000

1500

750

2000

2500

4000

300

400

2500

500

200

300

400

$\begin{array}{llll}5 & 00 & 40 & 00\end{array}$

$\begin{array}{llll}6 & 00 & 50 & 00\end{array}$

$\begin{array}{llll}4 & 00 & 30 & 00\end{array}$

$\begin{array}{llll}5 & 00 & 3500\end{array}$

WASHINGTON Golden, 9 to 12 in.................. 750

5000

\section{EVERGREEN SHRUBS.}

BOX TREE-Broad-LEAved, 9 to 12 in................. 250

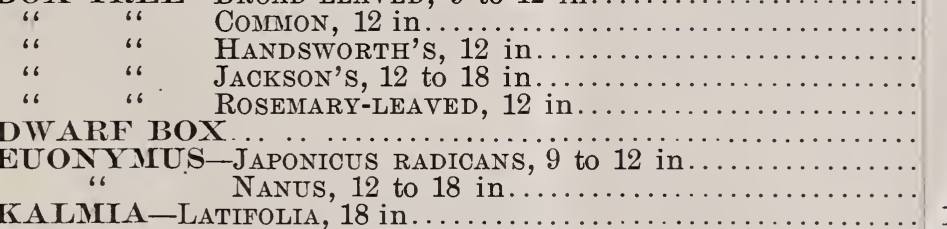

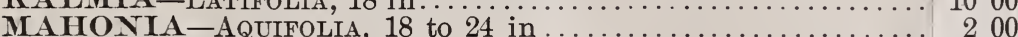

RHODODENDRON-HYBRIDS .......................... 1000

\section{0}

250

250

250

150

200

250

1000

200
10 00

1500

\section{DECIDUOUS SHRUBS.}

ALMOND-Dwarf Double Red, 2 to $3 \mathrm{ft} \ldots \ldots \ldots \ldots \ldots \ldots . \ldots 200$

" " " WHITE, 2 to $3 \mathrm{ft} \ldots \ldots \ldots \ldots \ldots 200$

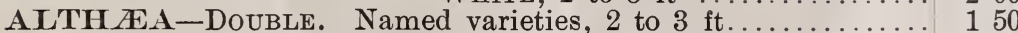

1000

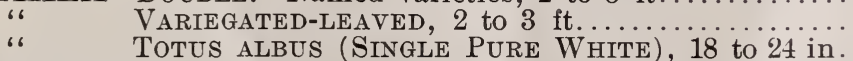

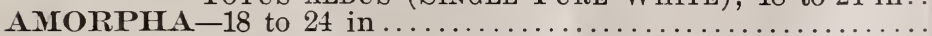


BACCHARIS-HALIMIFOLIA, 2 to $3 \mathrm{ft}$

Per $10 \mid$ Per 100

BARBERRY-HOLLY-LEAVED, 18 to 24 in

$\$ 150 \$ 1000$

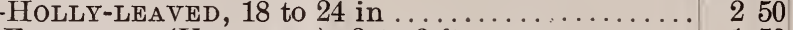

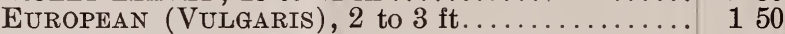

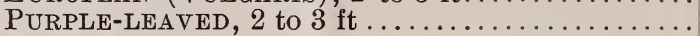

Thunberg's (B. Thunbergit), 18 to 24 in

BUCKTHORN -3 to $4 \mathrm{ft}$.

1000

$150 \quad 1000$

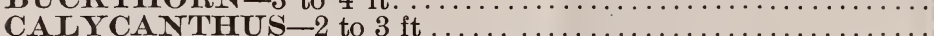

$150 \quad 1000$

$150 \quad 800$

CARAGANA-ARBORESCENS, 2 to $3 \mathrm{ft}$.

$150 \quad 1000$

CARYOPTERIS-MASTACANTHUS, 18 in

$\begin{array}{llll}1 & 50 & 10 & 00\end{array}$

CEANOTHUS-AMERICANUS, 12 to 18 in.

CEPHALA N'THUS-OCOIDENTALIS, 2 to $3 \mathrm{ft}$

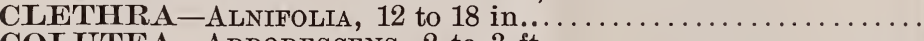

COLUTEA-ARBORESCENS, 2 to $3 \mathrm{ft} \ldots \ldots \ldots \ldots \ldots \ldots \ldots \ldots \ldots$

CORNUS-ALTERNIFOLIA, 2 to $3 \mathrm{ft}$.

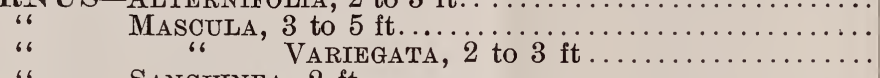

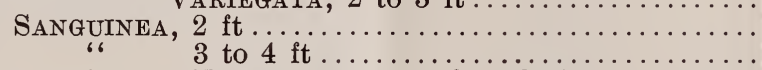

" ELEGANTISSIMA, 18 to 24 in

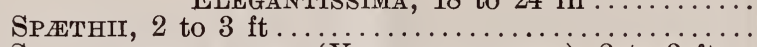

STOLONIFERA AUREA (YELLOW-BARKED), 2 to $3 \mathrm{ft}$.

RED-BARKED, 2 to $3 \mathrm{ft} \ldots \ldots \ldots \ldots \ldots$

CURRAN'T-AUREUM (YELLOW-FLOWERED), 18 to 24 in...........

$150 \quad 1000$

150

$150 \quad 1000$

$150 \quad 1000$

$150 \quad 1000$

150

$150 \quad 1000$

200

$150 \quad 800$

$200 \quad 1000$

$\begin{array}{llll}2 & 00 & 15 & 00\end{array}$

250

$200 \quad 1500$

$150 \quad 1000$

$150 \quad 1000$

...... 150

DEUTZIA-CRENATA FL. PL. (DOUBLE PINK), 2 to 3 ft........

200

150

800

800

Gracilis, 18 to 24 in.... ALBA (Double White), 3 to 4 .

150

200

800

"6 Campanulata, 2 to $3 \mathrm{ft}$.

" ROSEA, 2 to $3 \mathrm{ft} . .$.$\} Lemoine's$

" VENUSTA, 2 to $3 \mathrm{ft} \ldots . .$.

200

200

200

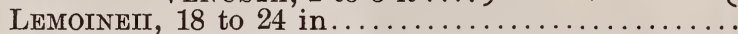

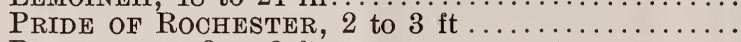

150

150

1000

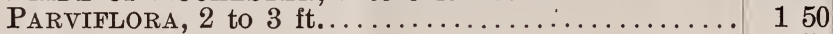

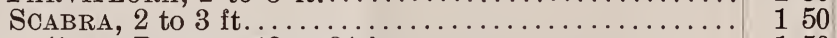
" DWARF, 18 to 24 in......................... 150

EL AAGNUS-ARgENTEA, 2 to $3 \mathrm{ft} \ldots \ldots \ldots \ldots \ldots \ldots \ldots \ldots \ldots$

150

LONGIPES, 2 to $3 \mathrm{ft}$.

ELDER-ACUTILOBA, $3 \mathrm{ft}$. Beautiful new Cut-leaved Elder.

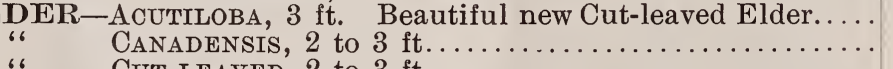

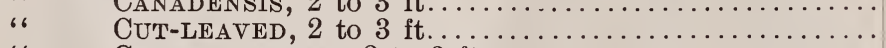

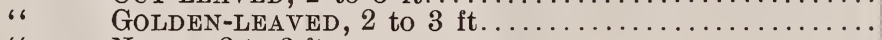

" NIGRA, 2 to $3 \mathrm{ft}$. .

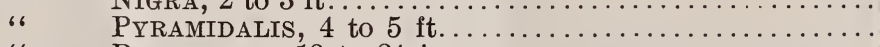

"RUONYMUS-EUROPEAN RED AND WHITE FRUITED, 2 to $3 \mathrm{ft} \ldots$

EXOCHORDA -2 to $3 \mathrm{ft}$.

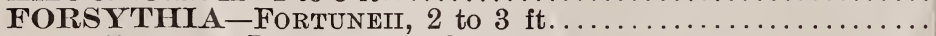

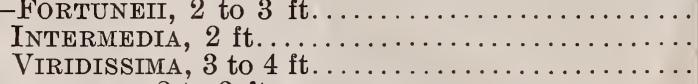
$\begin{array}{cc}\because 6 & \text { INTERMEDIA, } 2 \mathrm{ft} . \ldots \\ \text { FILBERT-CUT-LEAVISIMA, } 3 \text { to } 4 \mathrm{ft} .\end{array}$

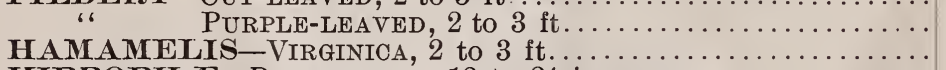

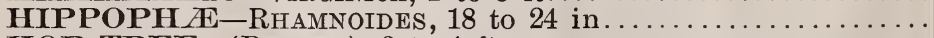

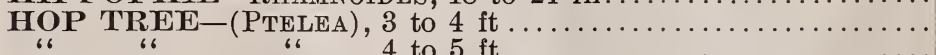

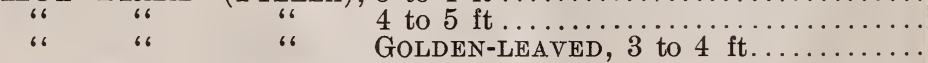

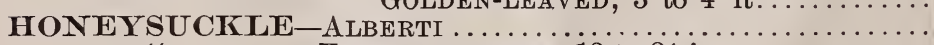

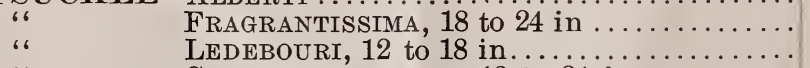

LEDEBOURI, 12 to 18 in ..................

"6 RUBRA, 2 to $3 \mathrm{ft}$.

1000

150

150

150

150

150

150

150

$150 \quad 1000$

$200 \quad 1500$

$150 \quad 1000$

$\begin{array}{llll}150 & 1000\end{array}$

$150 \quad 1000$

250

250

250

150

150

200

250

150

150

150

150

$150 \quad 1000$

2000

1000

1000

1000

66

1 
HONEYSUCKLE-RED TARTARIAN, 18 to 24 in

WhITE TARTARIAN, 2 to $3 \mathrm{ft}$

BELla ALBIDA, 18 to 24 in...

BELLA CANDIDA, 12 to 18 in

BELLA ROSEA, 18 to 24 in.

MoRRowI, 12 to 18 in ....
RUPRECHTIANA, 2 to $3 \mathrm{ft}$.

HYDRANGEA-PANICULATA GRANDIFLORA, 12 to 18 in

$\begin{array}{lll}66 & 6 & \mathrm{ft} . \ldots \ldots \ldots \ldots \\ 66 & \text { Tree form, } 3 \mathrm{ft} \ldots\end{array}$

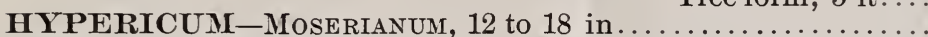

JAPAN QUINCE-BLUSH AND UMBBLLICATA, 2 to $3 \mathrm{ft} \ldots \ldots \ldots$

"6
6

KERRIA-JAPONICA, 18 to 24 in

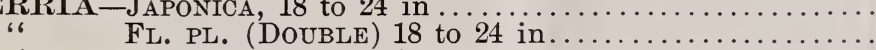

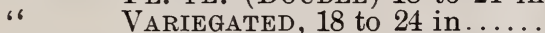

LAURUS-BENZOIN, 18 to 24 in.

LILAC-ALBA GRANDIFlORA (White), 2 to $3 \mathrm{ft} \ldots \ldots \ldots \ldots \ldots \ldots$

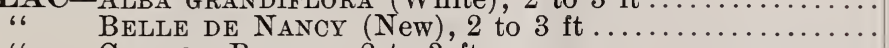

Common PuRple, 2 to $3 \mathrm{ft}$.

"6 6 WHITE, $2 \mathrm{ft} \ldots . . . . .$.

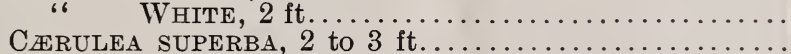

ChaRles X., 2 to $3 \mathrm{ft} \ldots .$.

JAPONICA, 2 to $3 \mathrm{ft}$

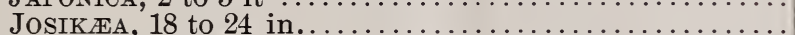

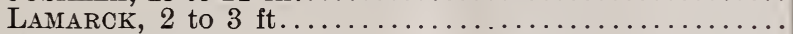

Mue. Lemorne, 2 ft. New double white..............

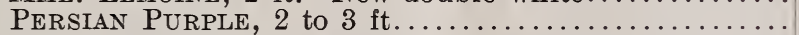

President Grevy, 2 to $3 \mathrm{ft}$.

PRINCESS Alexandra (White), 18 to 24 in................

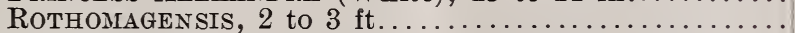

Siberian WhITE, 2 to $3 \mathrm{ft}$. . .

Villosa, 2 to $3 \mathrm{ft}$

"6 OUR AsSORTMENT, good sorts, 2 to $3 \ldots \ldots \ldots \ldots \ldots \ldots$

MYRICA-CERIFERA, 12 in

PHILADELPHUS-See Syringa.

PRINOS-Verticillata, 18 to 24 in.

PRIVET-CALIFORNIA, 18 to 24 in..

18 to 24 in ............. $\$ 30$ per 1000

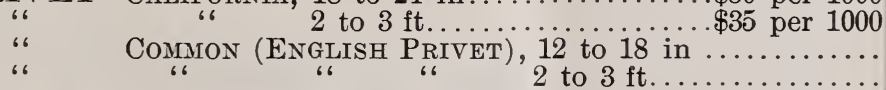

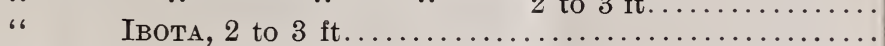

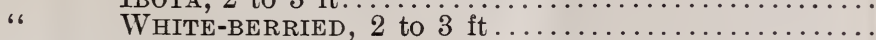

PRUNUS-PISSARDI, 4 to $5 \mathrm{ft}$. Purple-leaved Plum. Retains its color throughout season....................

" TRILOBA (DOUBLE-FLOWERED), 2 to $3 \mathrm{ft} \ldots \ldots \ldots \ldots$

PURPLE FRINGE-3 to $4 \mathrm{ft}$

QUINCE-JAPAN-See Japan Quince.

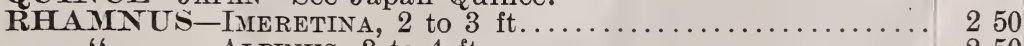

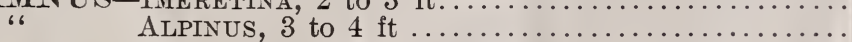

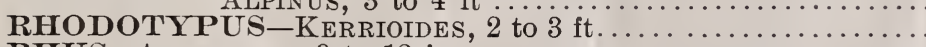

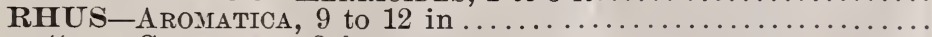

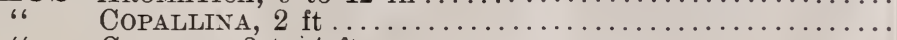

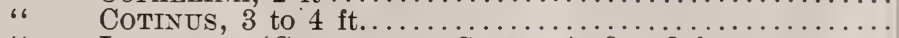

" Laciniata (CuT-Leaved SuMACH), 2 to $3 \mathrm{ft} . \ldots \ldots \ldots \ldots$

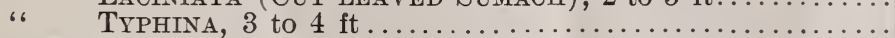

SNOWBERRY-See Symphoricarpus.

SPIRAEA-ANTHONY WATERER (new, superb), 12 to 18 in....

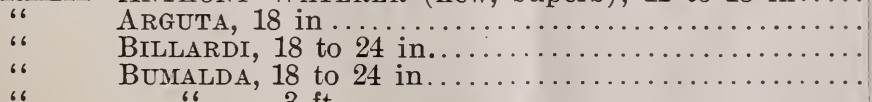

Per 10 Per 100

$\$ 150 \$ 1000$

150

$150 \quad 1000$

$150 \quad 1000$

$150 \quad 1000$

$150 \quad 1000$

$150 \quad 1000$

$150 \quad 600$

$\begin{array}{llll}2 & 00 & 10 & 00\end{array}$

250

$200 \quad 1500$

$150 \quad 1000$

$150 \quad 800$

250

150

150

150

150

250

250

150

150

200

200

200

200

250

250

200

250

250

200

200

200

250

150

1000

1000

1000

1500

2000

1500

2000

200

100

150

100

150

150

150

$\begin{array}{llll}2 & 00 & 15 & 00\end{array}$

$\begin{array}{llll}2 & 00 & 12 & 00\end{array}$

$150 \quad 1000$

250

$\begin{array}{ll}1 & 50 \\ 2 & 00\end{array}$

200
200

150

200

200

1000

1500

1500

1000

$\begin{array}{llll}2 & 00 & 10 & 00\end{array}$

$\begin{array}{llll}150 \quad 1000 & 00\end{array}$

$\begin{array}{llll}150 & 1000\end{array}$

$\begin{array}{lll}150 & 800\end{array}$

66

$3 \mathrm{ft}$

$\begin{array}{llll}2 & 00 & 1000\end{array}$ 


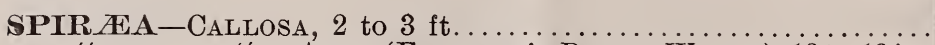
Per 10 Per 100 " " Alba (ForTune's DWARF White), 12 to 18 in.

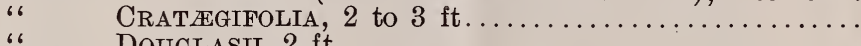

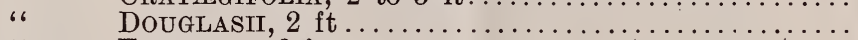

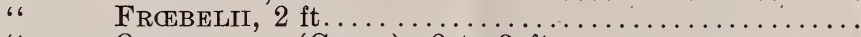

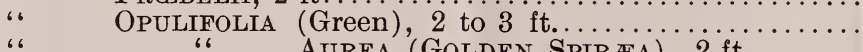
"، $\quad$ PrUnifolia, Fu. PL., 3 to $4 \mathrm{ft} \ldots \ldots \ldots \ldots \ldots \ldots \ldots \ldots$

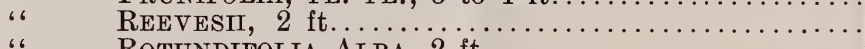

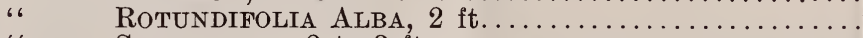

"6 SALICIFOLIA, 2 to $3 \mathrm{ft}$.

" SORBIFOLIA, 2 to $3 \mathrm{ft}$

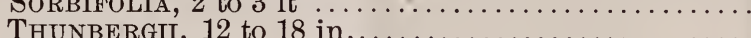

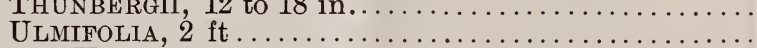

"، ULMifolia, $2 \mathrm{ft} \ldots \ldots \ldots$

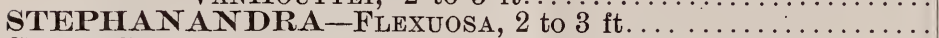
SUMACH-See Rhus.

SYMPHORICARPUS-VULGARIS (INDIAN CURRANT), $2 \mathrm{ft}$.... RACEMOSUS (SNOWBERRY), 2 to $3 \mathrm{ft}$...

$\$ 150 \$ 1000$

$150 \quad 1000$

$150 \quad 1000$

150

150

$150 \quad 1000$

$150 \quad 1000$

$150 \quad 1000$

$\begin{array}{llll}1 & 50 & 10 & 00\end{array}$

150

$150 \quad 1000$

$150 \quad 1000$

$150 \quad 1000$

150

$150 \quad 1000$

SYRINGA-(Philadelphus, Mock Orange).

"6 CoRONARIUS, 2 to $3 \mathrm{ft}$.

" CORDATA, 12 to 18 in

200

150

800

$150 \quad 800$

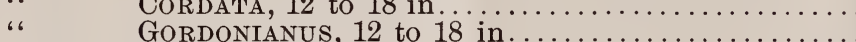

GORDONIANUs, 12 to 18 in $\ldots \ldots \ldots \ldots \ldots \ldots \ldots \ldots$

GRANDIFLORUS, $2 \mathrm{ft} \ldots \ldots \ldots \ldots \ldots \ldots \ldots \ldots \ldots \ldots$

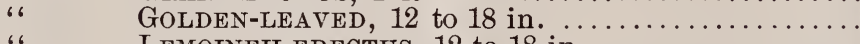

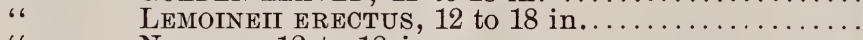

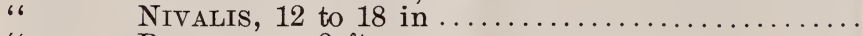

"، Pubescens, $2 \mathrm{ft}$.

"SPECIOSUS, $2 \mathrm{ft}$.

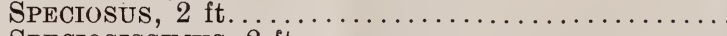

$1.50 \quad 1000$

$150 \quad 1000$

$150 \quad 1000$

$150 \quad 1000$

$200 \quad 1200$

$150 \quad 1000$

$150 \quad 1000$

$150 \quad 1000$

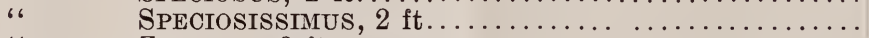

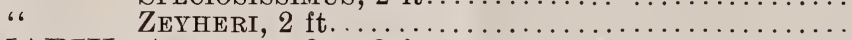

$150 \quad 1000$

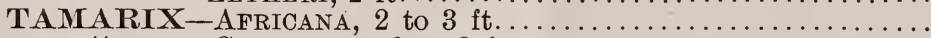

150

$150 \quad 1000$

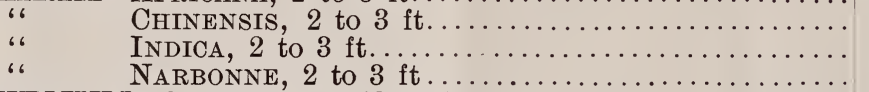

150

150

150

150

250

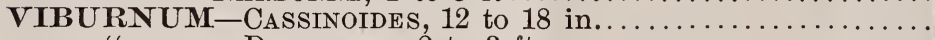

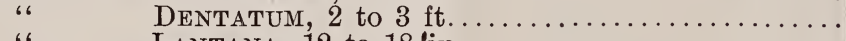

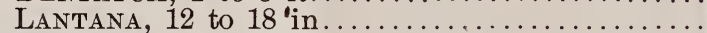

"6 $\quad$ MENTAGO, 2 to $3 \mathrm{ft}$.

" NANUM, 12 in.

" Opulus, 18 to 24 in. High Bush CRANBerRy.

"، Plicatum (Japan SNOWBalL), 18 to 24 in......

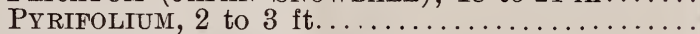

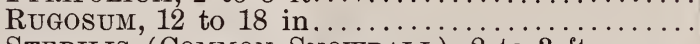

STERILIS (ComMon SNOWBALL), 2 to $3 \mathrm{ft} . \ldots \ldots$.

200

150

200

200

150

150

250

250

66

Tomentosum, 18 to 24 in.

150

150

200

150

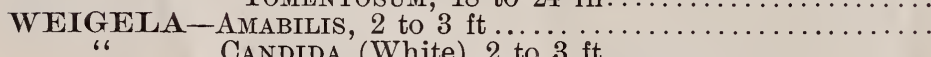

150

$\begin{array}{llll}1 & 50 & 10 & 00\end{array}$

"، DESBOISII, 18 to 24 in .

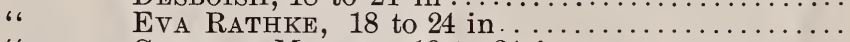

66

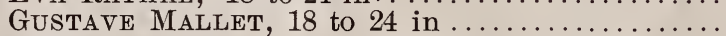

66

Rosea, 2 to $3 \mathrm{ft}$.

200

150

150

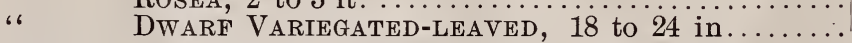

$\begin{array}{llll}1 & 50 & 10 & 00\end{array}$

\section{Pin Oaks}

(See Page 8) 


\section{CLIMBING SHRUBS.}

ACTINIDIA-Arguta and Polygana

AKEBIA-QUINATA

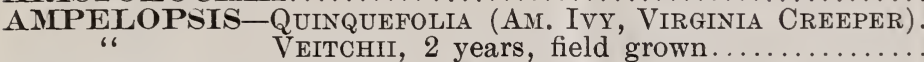

BIGNONIA-RADICANS (TRUMPET FLOWER) . . . . . . . . .

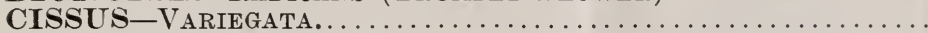

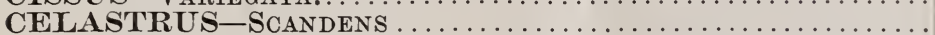
Paniculatus.

CLEMATIS-COCCINEA

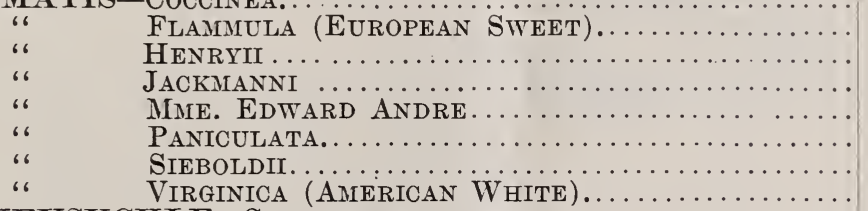

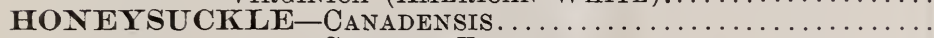

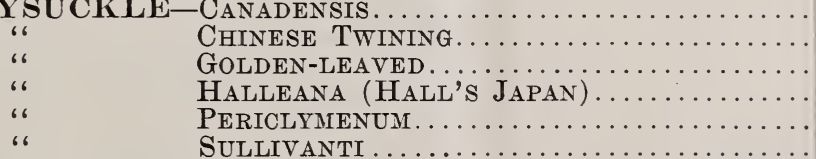

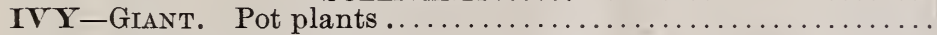

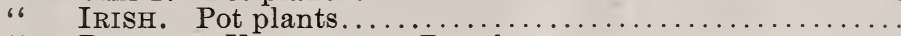

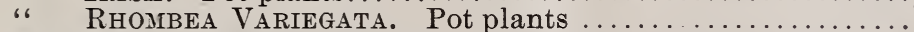

LYCIUMI- (MATRINONY VINE)

PERIPLOCA-GRACA (SILK VINE).

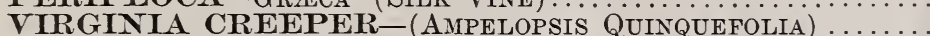

WISTARIA-ChINESE PURPLE.

WHITE

\section{HEDGE PLANTS.}

BARBERRY-THUNBERGII, 18 to 24 in

PRIVET CALIFORNIA, 18 to 24 inches

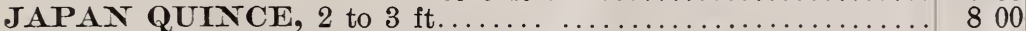

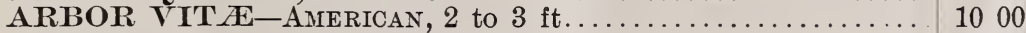

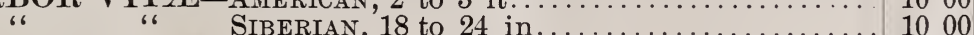

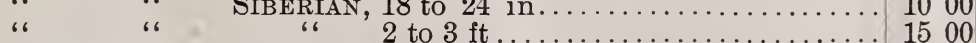

HONEY LOCUST-1 year............................... 200

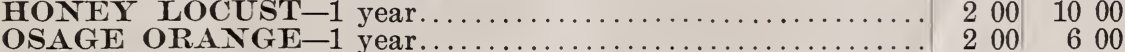

\section{Fine Stock of \\ Oriental Planes, \\ Willows, Poplars.}




\section{ROSES.}

One of Our Leading Specialties. Strong, Field-grown Plants. All of our own growing.

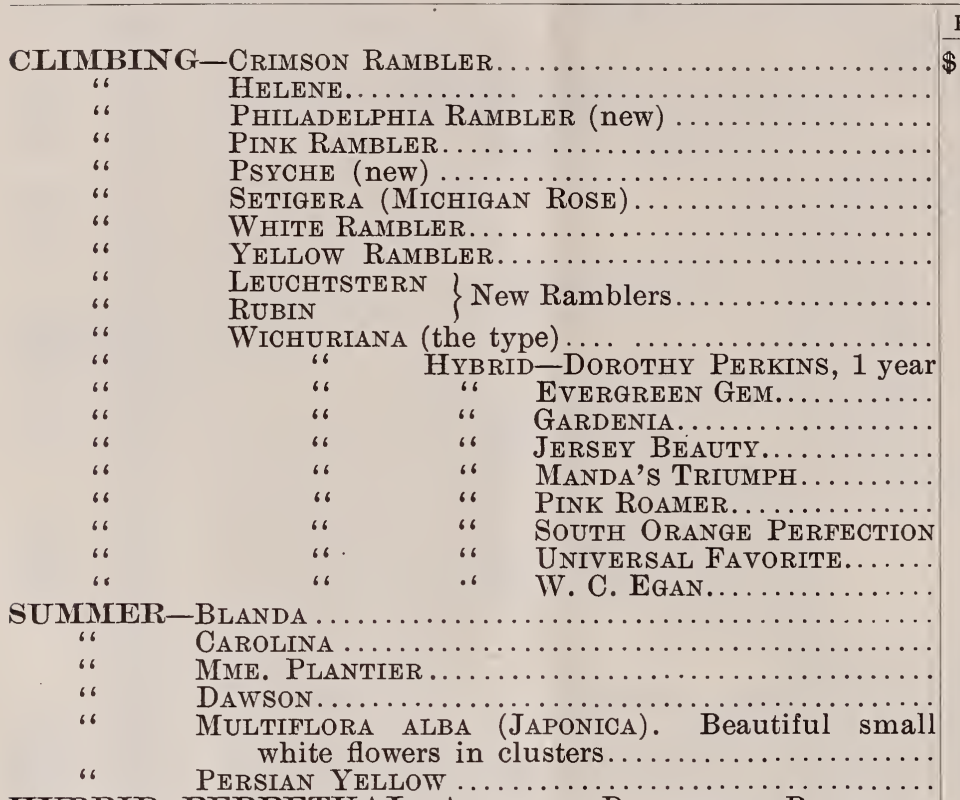

HYBRID PERPETUAL-ANNE DE DIESBACH, BARON DE Per 10 Per 100 $\$ 150 \$ 1200$ 150

$200 \quad 1500$ $150 \quad 800$ 150

$150 \quad 800$

150

$\begin{array}{llll}150 & 10 & 00\end{array}$

$150 \quad 1200$

$150 \quad 800$

$\begin{array}{llr}2 & 00 & 1200\end{array}$

150

150

150

150

150

150

150

$\begin{array}{llll}1 & 50 & 10 & 00\end{array}$

$\begin{array}{llll}1 & 50 & 10 & 00\end{array}$

$150 \quad 800$

$\begin{array}{llll}1 & 50 & 12 & 00\end{array}$

$\begin{array}{lll}150 & 1200\end{array}$

$150 \quad 600$

$\begin{array}{lll}2 & 00 & 1500\end{array}$

Bonstetten, Baroness Rothschild, Eugene Furst, Francois Levet, Gen. Jacqueminot, Mme. Gabriel Luizet, Magna Charta, Margaret Dickson, Mrs. John Laing,

PaUl Neyron, Prince Camille de Rohan ..............

HYBRID RUGOSA-MME. G. BRUANT, pure white, extra hardy.

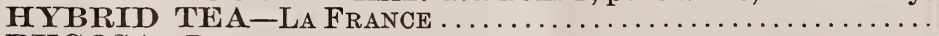

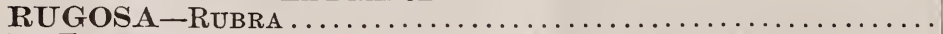

POLYANTHA-CLOTHILdE SoUPERT. Pot plants ............

BOURBON-HERMOSA. Pot plants $\ldots \ldots \ldots \ldots \ldots \ldots \ldots \ldots \ldots$

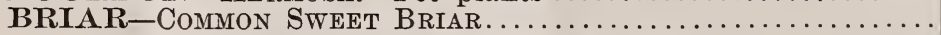

NEW HARDY YELLOW ROSE.

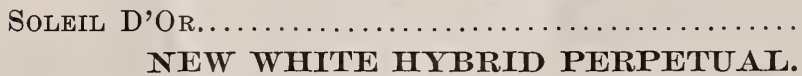

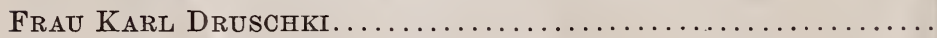

$200 \quad 1200$

$200 \quad 1200$

$200 \quad 1500$

$150 \quad 1000$

$200 \quad 1500$

$200 \quad 1500$

$150 \quad 600$

$300 \quad 2000$

$300 \quad 2500$

NEW HARDY EVERBLOOMING ROSE.

Mme. Norbert Levavasseur (Dwarf Crimson Rambler)..... $500 \quad 5000$ TREE ROSES.

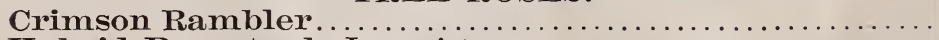

$400 \quad 3500$

Hybrid Perpetual-In variety ..................... 400

TREE P AONIES.

BANKSII-Chinese Double Blush, first-class ........... 500

HERBACEOUS P AONIES.

CHINESE-Selected Varieties, Pink and Red............ 2001000 “6 TENUIfolia FL. PL......................... $250 \quad 2000$ 


\section{HARDY PHLOXES. A Superb Collection.}

$\frac{\text { Per } 10}{\$} \frac{\text { Per } 100}{\$}$

Amazone-Pure white. The finest of its color .............

Belvedere-Salmon pink, crimson eye. Distinct.

$150 \quad 800$

Hemi . . . . . . . . .

150

600

La Vague-Beautiful silvery rose, crimson eye ..............

Lothail-Large truss, salmon color, crimson eye. One of the finest

Pantheon-Large florets, pink. A beautiful shade.

150

150

800

150

600

150

500

Pharaon-Light purple, white star-shaped center. Distinct and fine Queen-Pure white.

Richard Wallace-Large truss, white, with violet ey

Our Selection of Varieties ..................... \$50 per 1000

\section{HARDY BORDER PLANTS.}

Our collection is one of the largest in this country, and the plants are fine. Particular attention is invited to the following:

ACHILLEA-IN VARIETY

ACONITUM-UNCINATUM

AJUGA-REPTANS ALBA...

RUBRA. .

ALYSSUM-ARGENTEUM

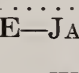

"6

WHIRLWIND

RUBRA.

Queen Charlotte (new)

AQUILEGIA-In variety

ARABIS-ALPINA.

ARMERLA-MARITIMA

ARUNDO-DONAX .

ARUNDINARIA-FOLIIS VARIEGATIS.

ASPERUI A-ODORATA.

ASPHODELINE-LUTEA . . .

ASTER-In variety. .

ASTILBE-JAPONICA.

AUBRETIA

BOCCONIA

C...................

BOLTOYI-L

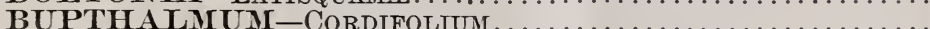

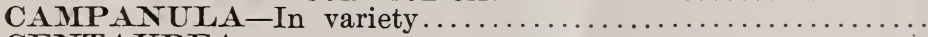

CENTAUREA ................

CERASTIUM.

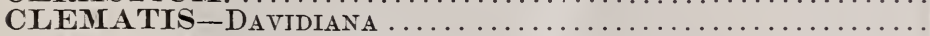

CENTRA NTHUS-ALBUS

COREOPSIS.

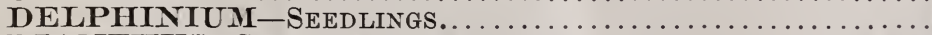

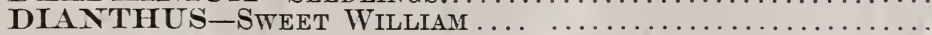

DICENTRA-SPECTABILIS. . . . . . . . . . . . . . . .

DORONICUMI-In variety.

ECHINOPS-HUMILIS. .

ERIANTHUS-RAVENNA.

EULALIA - GRACILLIMA UNIVITTATA.

FUNKLA-GRANDI

HELIANTHEMUII-In variety.

HELIANTHUS - ITUL

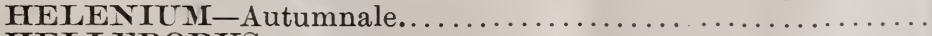

HELLIEBORS

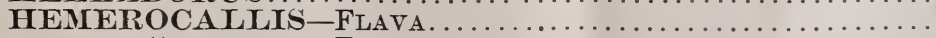

THUNBERGII. .
150

800

800

600

600

150

150

600

600

150

150

150

150

150

150

150

150

150

150

150

150

150

150

150

150

150

150

150

150

150

150

150

150

150

150

150

150

150

150

150

150

250

150

150

150 


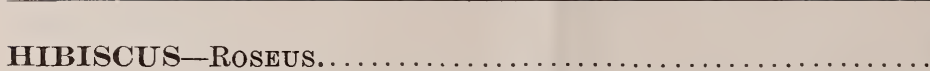
\begin{tabular}{|l|l|l|} 
Per 10 & Per 100
\end{tabular} $\$ 150 \$ 600$ "6 ALBUS.. $150 \quad 800$

INCANUS.

$150 \quad 600$

6 MOSCHUETOS

$150 \quad 600$

HOLLYHOCKS-DOUBLE. Fine assortment of colors

$150 \quad 800$

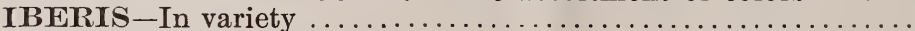

$150 \quad 1000$

IRIS-GERMAN. In variety

$150 \quad 600$

TYSIMAPAN MIXED................

$150 \quad 800$

等

$150 \quad 600$

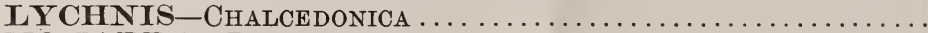

150

800

MONARDA-DIDYM

OENOTHERA.

150

600

$150 \quad 600$

PAPAVER-ORIENTAL

PHLOX-SUBULATA ALBA.

$150 \quad 800$

$150 \quad 800$

" AMCENA.

RUBRA

PLATYCODON-In variety

PRIMULA - In variety ........

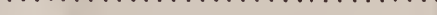

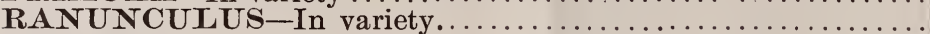

RUDBECKIA-LaCINIATA FL. PL. (GOLdEN GLOW) In variety

SALVIA - In variety

SANGUINARIA.

150

800

$150 \quad 800$

$150 \quad 600$

$150 \quad 600$

150

$150 \quad 400$

$150 \quad 800$

150

150

150

SEDUM

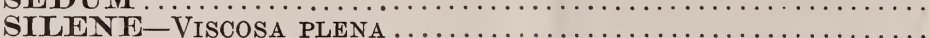

150

150

150

SPIR AA-(ASTILBE) JAPONICA

" In variety

150

STACHYS-LANATA.

STOKESIA-CYANEA.

TRILLIUM

$150 \quad 800$

$150 \quad 800$

VINCA-In variety.

VERONICA-In variety

YUCCA-Filamentosa.

150

$150 \quad 800$

$150 \quad 800$

$150 \quad 800$

Fine collections - our assortment of varieties, $\$ 8$ per 100 , $\$ 50$ per 1000 .

\section{Clematis paniculata Strong Plants}




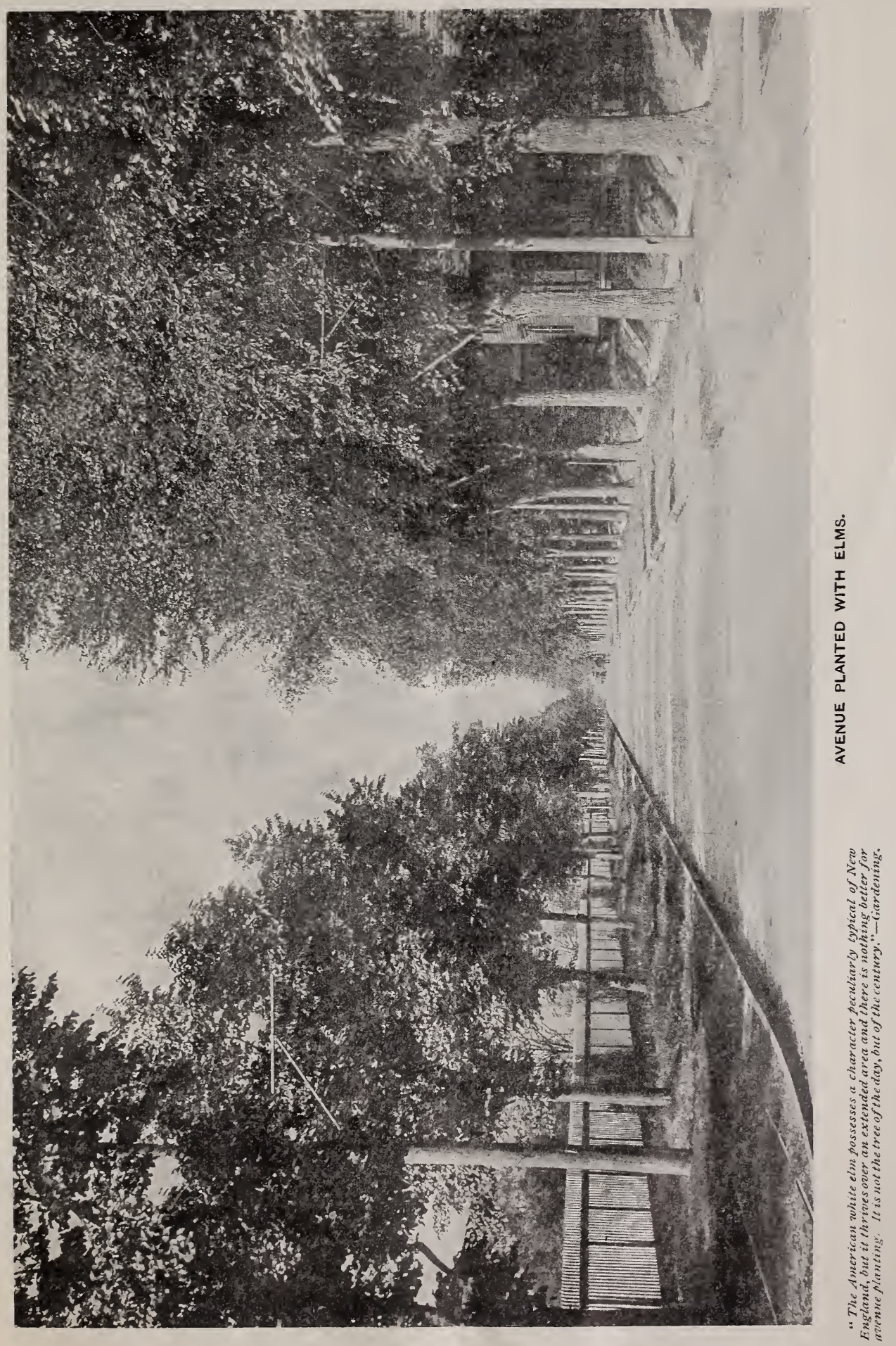




\section{Leading Specialties}

\section{FOR SPRING, 1905.}

DWARF PEARS-Angouleme.

RASPBERRY-Marlboro.

GRAPES-Campluell's Early; Concord.

BEECH-Common Purple, Rivers' Purple; Grafted, true purple. CATALPA.

ELM-American, 8 to $10 \mathrm{ft}$; 10 to $12 \mathrm{ft}$.

HORSE CHESTNUT-Red-flowered.

MAPLE-Silver-leaved, 8 to $10 \mathrm{ft}$; Wier's Cut-leaved, 8 to $10 \mathrm{ft}$. OAK-Pin, 6 to $8 \mathrm{ft}$; 8 to $10 \mathrm{ft}$.

PLANE-Oriental, 8 to $10 \mathrm{ft}$; 10 to $12 \mathrm{ft}$.

POPLAR-Carolina, 8 to $10 \mathrm{ft}$.

WILLOWS-In variety (fine).

ARBOR VITA-American (fine), 4 to $5 \mathrm{ft}$.

CORNUS-Sanguinea.

FORSYTHIA VIRIDISSIMA.

LILAC-Common Purple, 2 to $3 \mathrm{ft}$.

SPIR AA-Bumalda.

SNOWBERRY, 2 to $3 \mathrm{ft}$.

INDLAN CURRANT, $2 \mathrm{ft}$.

HARDY PHLOX-Distinct Varieties.

COMMON SWEET BRIAR ROSE.

ROSA SETIGERA.

\section{NOVELTIES}

NEIV ANEMONE-Queen Charlotte. (For price, see page 17.)

NEW CUT-LEAVED AMERICAN ELDER-Sambucus Acutiloba.

(For price, see page 12.)

NEW ROSES-Leuchtstern; Rubin; Philadelphia Rambler ; Frau

Karl Druschki; Mme. Norbert Levavasseur. 